\title{
Multiplicação fotoautotrófica in vitro de pereiras 'Abate Fetel'
}

\author{
Photoautotrophic multiplication in vitro of 'Abate Fetel' pears
}

\section{Fernando José Hawerroth ${ }^{\mathrm{I}^{*}}$ André Luiz Külkamp de Souza ${ }^{\mathrm{I}}$ Luana Borges Affonso Daniele Camargo Nascimento ${ }^{I}$ Márcia Wulff Schuch ${ }^{\mathrm{I}}$}

\begin{abstract}
Novas cultivares de pereira têm sido introduzidas no Brasil, como a 'Abate Fetel'. A produção de mudas de qualidade dessa cultivar é necessária, sendo possível obter tal cultivar pelo uso de técnicas de micropropagação. Objetivouse avaliar diferentes concentrações de sacarose e tipos de vedação dos frascos na multiplicação in vitro de pereiras 'Abate Fetel'. Segmentos nodais contendo de duas a três gemas axilares, de aproximadamente $1 \mathrm{~cm}$ de comprimento, oriundos de plantas pré-estabelecidas in vitro, foram inoculados em meio de cultura ' $Q L$ ', suplementados com mio-inositol $(100 \mathrm{mg}$ $\left.L^{-1}\right)$, sacarose $\left(0,15,30,45 g L^{-1}\right), B A P\left(1 m g L^{-1}\right), A I B(0,1 m g$ $\left.L^{-1}\right)$ solidificado com $6,5 \mathrm{~g} L^{-1}$ de ágar e pH ajustado para 5,7 . Os frascos foram vedados com algodão, aluminio ou filme plástico de PVC e mantidos em sala de crescimento a $25 \pm 2^{\circ} \mathrm{C}$, com intensidade luminosa de $42 \mu$ moles $\mathrm{m}^{-2} \mathrm{~s}^{-1}$ e fotoperiodo de 16 horas. Os frascos vedados com algodão apresentaram o maior número de folhas na ausência de sacarose, não sendo observado efeito das concentrações de sacarose presentes no meio de cultura sobre o número de brotações e número de folhas formadas. O comprimento médio das brotações e a massa fresca total não diferiram entre os tipos de vedação empregados, porém observou-se aumento expressivo dessas variáveis frente ao aumento da sacarose no meio de cultura. A vedação dos frascos com filme de PVC proporcionou o maior número de brotações por explante quando utilizadas altas concentrações de sacarose.
\end{abstract}

Palavras-chave: Pyrus communis, vedação dos frascos, sacarose, explantes.

\section{ABSTRACT}

New pear cultivars have been introduced in Brazil as the 'Abate Fetel'. Seedling production with higher quality of this cultivar is needed, and this can be obtained by use of micropropagation techniques. The objective of the present study was to evaluate different sucrose concentrations and types of closure flasks on micropropagation of 'Abate Fetel' pears. Nodal segments with two to three axillary buds, about $1 \mathrm{~cm}$ in length, from plants pre-established in vitro, were inoculated on ' $Q L$ ' culture medium supplemented with myo-inositol (100mg $\left.L^{-1}\right)$, sucrose $\left(0,15,30,45 g L^{-1}\right), B A P\left(1 m g L^{-1}\right), I B A\left(0.1 m g L^{-1}\right)$ solidified with $6.5 \mathrm{~g} \mathrm{~L}^{-1}$ agar and $\mathrm{pH}$ adjusted to 5.7. The flasks were closured with cotton, aluminum or PVC plastic film and kept in a growth chamber at $25 \pm 2^{\circ} \mathrm{C}$, light intensity of $42 \mu \mathrm{moles}$ $m^{-2} s^{-1}$ and $16 h$ of photoperiod. The flasks closured with cotton showed the highest number of leaves formed in the absence of sucrose and it was not observed effect of sucrose concentration in the culture medium of shoots number and number of leaves formed. The average shoot length and the total fresh weight did not differ between the types of closure flasks used, but there was a significant increase of these variables against the sucrose increase in the culture medium. The closure flasks with PVC film showed the highest number of shoots per explant, when high sucrose concentrations was used.

Key words: Pyrus communis, flasks closure, sucrose, explants.

A utilização de mudas com elevado padrão de qualidade morfofisiológica e fitossanitária na implantação de pomares é decisiva para viabilização do sistema de produção de frutas, sobretudo em culturas em expansão, a exemplo da cultura da pereira (Pyrus spp.) no Sul do Brasil. Novas cultivares têm sido introduzidas no país, podendo ser destacada a cultivar 'Abate Fetel', a qual pode ser propagada por

'Programa de Pós-graduação em Agronomia, concentração em Fruticultura de Clima Temperado, Departamento de Fitotecnia, Faculdade de Agronomia 'Eliseu Maciel' (FAEM), Universidade Federal de Pelotas (UFPEL), Campus Universitário Capão do Leão, CP 354, 96010-900, Pelotas, RS, Brasil. E-mail: fjhawerroth@gmail.com.br. *Autor para correspondência. 
meio da micropropagação, proporcionando a obtenção de mudas sadias em curto espaço de tempo. Entretanto, o emprego da micropropagação em escala comercial na produção de mudas pode ser limitado, devido, entre outros fatores, ao elevado custo para obtenção da muda (ERIG \& SCHUCH, 2005).

Em busca de alternativas para reduzir os custos da micropropagação convencional e melhorar a qualidade fisiológica das plantas produzidas, aumentando a sobrevivência durante o período de aclimatização, destaca-se o desenvolvimento da micropropagação fotoautotrófica (DAMIANI \& SCHUCH, 2009). Esse método consiste na produção de micropropágulos sob condições ambientais que maximizem a fotossíntese, de modo a diminuir riscos de contaminação microbiana pela diminuição de sacarose no meio de cultura, reduzir custos de produção e melhorar características fisiológicas da planta, facilitando sua aclimatização às condições ex vitro (AFREEN et al., 2002).

Entre as práticas utilizadas para promover o crescimento fotoautotrófico das plantas in vitro, destaca-se a eliminação total ou parcial da sacarose do meio de cultura (KOZAI \& KUBOTA, 2001), visto que a sacarose, açúcar mais utilizado na micropropagação, em teores elevados, pode inibir a síntese de clorofila nas espécies cultivadas (RODRIGUES et al., 2006). A utilização de diferentes sistemas de vedação de frascos pode ser efetiva em sistemas de micropropagação fotoautotrófica, visto que, segundo KOZAI \& KUBOTA (2001), o aumento da concentração de CO e diminuição da concentração de etileno e da umidade relativa dentro dos frascos de cultivo, assim como o aumento da intensidade luminosa, também podem aumentar a atividade fotossintética das plantas in vitro. Nesse sentido, objetivou-se avaliar diferentes concentrações de sacarose e tipos de vedação dos frascos na multiplicação in vitro de pereiras 'Abate Fetel' visando ao aperfeiçoamento de sistemas de micropropagação fotoautotrófica.

Segmentos nodais de pereiras 'Abate Fetel' (Pyrus communis L.), contendo de duas a três gemas axilares, com $1 \mathrm{~cm}$ de comprimento, oriundos de plantas pré-estabelecidas in vitro, foram inoculados em meio de cultura 'QL' descrito por QUOIRIN \& LEPOIVRE (1977) e modificado por LEBLAY et al. (1991), acrescido de diferentes concentrações de sacarose $(0,15,30,45 \mathrm{~g}$ $\left.\mathrm{L}^{-1}\right), 100 \mathrm{mg} \mathrm{L}^{-1}$ de mio-inositol, $1 \mathrm{mg} \mathrm{L}^{-1}$ de 6benzilaminopurina (BAP) e $0,1 \mathrm{mg} \mathrm{L}^{-1}$ de ácido indolbutírico (AIB). $\mathrm{O} \mathrm{pH}$ do meio de cultura foi ajustado para 5,7 antes da adição de $6,5 \mathrm{~g} \mathrm{~L}^{-1}$ de ágar. Foram distribuídos $50 \mathrm{~mL}$ de meio de cultura em cada frasco 'Erlenmeyer' de $250 \mathrm{~mL}$ de capacidade, sendo esterilizados em autoclave por 20 minutos à temperatura de $120^{\circ} \mathrm{C}$ e 1,5 atm de pressão.

Cinco explantes foram inoculados em cada frasco, em câmara de fluxo laminar, sendo os frascos vedados com algodão, alumínio e filme plástico de policloreto de vinila (PVC). Após a inoculação, os explantes foram mantidos em sala de crescimento a $25 \pm 2{ }^{\circ} \mathrm{C}, 16$ horas de fotoperíodo e intensidade luminosa de $42 \mu \mathrm{mol} \mathrm{m} \mathrm{m}^{-2} \mathrm{~s}^{-1}$. As avaliações foram realizadas 45 dias após a manutenção dos explantes em sala de crescimento, sendo mensurados o número e o comprimento médio das brotações, o número médio de folhas formadas e a massa fresca total.

O delineamento experimental foi inteiramente casualizado, com quatro repetições compostas de um frasco contendo cinco explantes, segundo um fatorial $4 \times 3$, obtido da combinação de quatro concentrações sacarose $\left(0,15,30,45 \mathrm{~g} \mathrm{~L}^{-1}\right)$ e três níveis do fator vedação dos frascos (alumínio, algodão e filme plástico de PVC). As variáveis foram transformadas a fim de atender as pressuposições da análise de variância, sendo efetuada a transformação raiz quadrada $(x+0,5)$. As variáveis significativas tiveram as médias comparadas pelo teste Tukey, a 5\% de significância, para o fator tipo de vedação, e para o fator sacarose foi efetuada a análise de regressão polinomial.

Em relação ao número de médio de brotações por explante, houve interação entre os fatores concentração de sacarose e tipo de vedação dos frascos (Tabela 1). Comparando os diferentes tipos de vedação estudados, foi verificada diferença significativa apenas na concentração de $30 \mathrm{mg} \mathrm{L}^{-1}$ de sacarose, destacando-se a vedação com alumínio, que apresentou média de 1,35 brotações por explante. $\mathrm{O}$ número médio de brotações apresentou resposta quadrática ao aumento da sacarose no meio de cultura, e a concentração de $23,3 \mathrm{mg} \mathrm{L}^{-1}$ de sacarose proporcionou máxima resposta para essa variável (Figura 1a). Concentrações de sacarose acima desse limite reduziram significativamente o número de brotações por explante com esse tipo de vedação, assim como observado por AHMAD et al. (2007) na multiplicação do porta-enxerto de pessegueiro 'GF-677'. De acordo com RODRIGUES et al. (2006), a sacarose em altas concentrações pode reduzir a síntese de clorofila, a qual, associada a menor passagem de luz e maior concentração de etileno e umidade no interior dos frascos vedados com papel alumínio, pode diminuir a fotossíntese, de forma a reduzir a formação de novos explantes, justificando a resposta observada neste estudo.

Quando os frascos foram vedados com filme de PVC, o número de brotações por explante aumentou 
Tabela 1 - Número médio de brotações e número médio de folhas formadas em explantes de pereiras 'Abate Fetel', em função de concentrações de sacarose no meio de cultura e tipos de vedação nos frascos de multiplicação. FAEM/UFPel, Pelotas/RS, 2009.

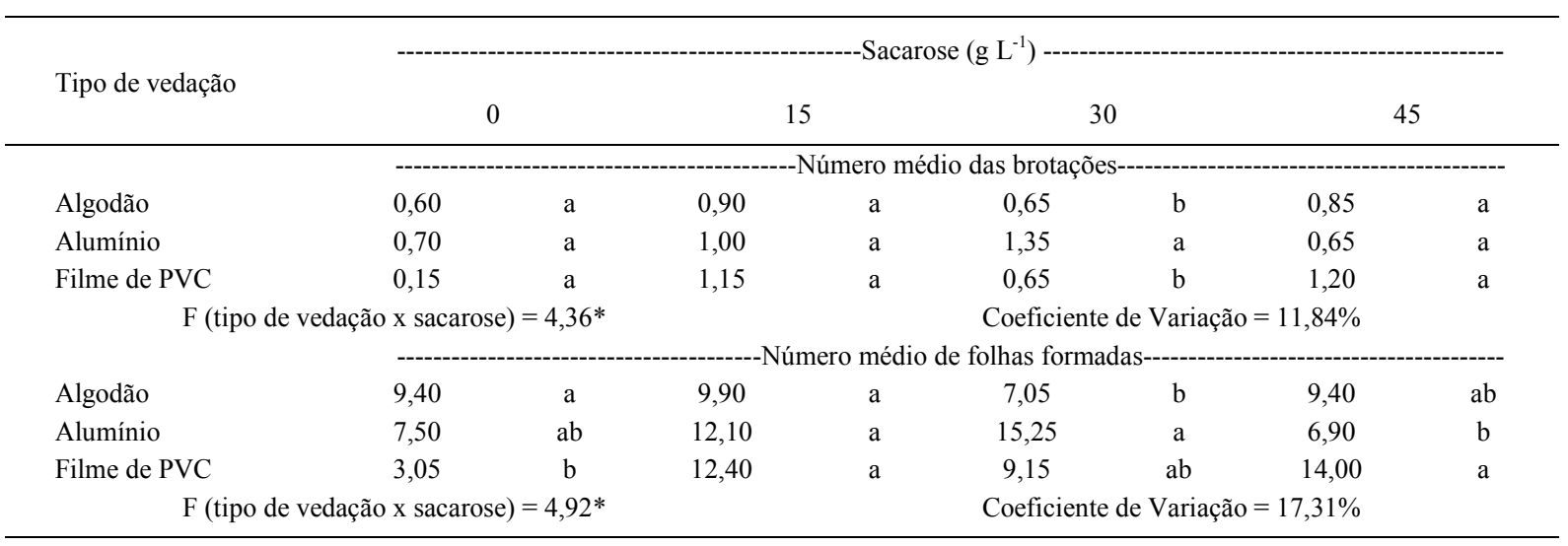

* Valor do teste $\mathrm{F}$ significativo a $5 \%$ de probabilidade de erro; Médias não seguidas de letras minúsculas iguais na coluna diferem significativamente pelo teste Tukey, a $5 \%$ de probabilidade de erro.

significativamente com o incremento das concentrações de sacarose, enquanto que, nos frascos vedados com algodão, o aumento da sacarose no meio de cultura não foi significativo, e a média manteve-se em 0,75 brotações por explante (Figura 1a). O efeito não significativo das concentrações de sacarose no número

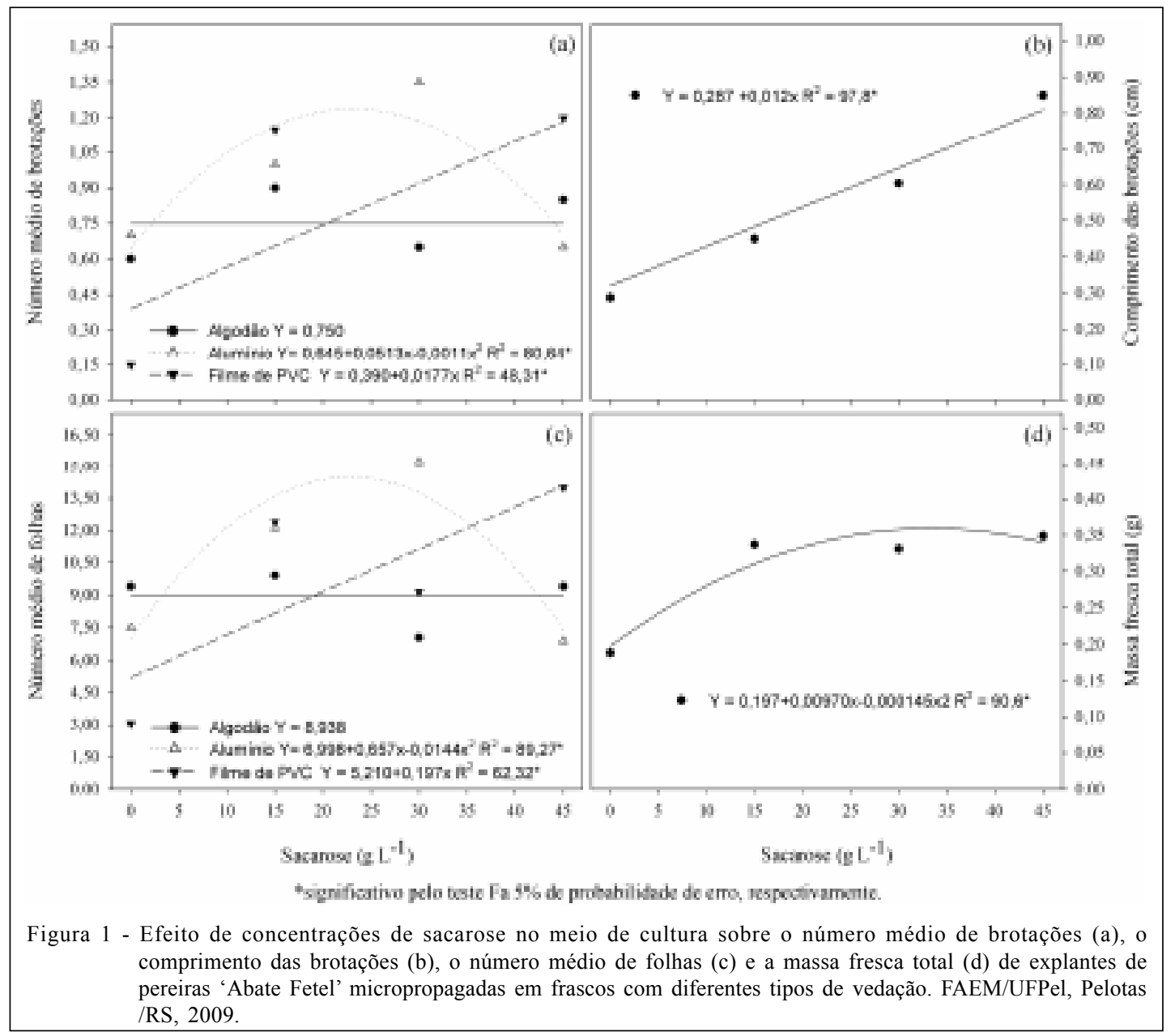

Ciência Rural, v.40, n.6, jun, 2010. 
médio de brotações por explante, observado nos frascos vedados com algodão, pode estar relacionado à maior permeabilidade a gases desse tipo de vedação. Segundo KOZAY \& NGUYEN (2003), esse fechamento dos frascos de cultivo pode favorecer as trocas gasosas, aumentando a concentração de $\mathrm{CO}_{2}$ e, simultaneamente, reduzindo a umidade relativa e a concentração de etileno. Tais condições podem ter maximizado a produção de fotoassimilados pela fotossíntese, diminuindo a necessidade da sacarose do meio de cultura como fonte de carboidratos para a formação de novos explantes.

O comprimento das brotações não foi afetado pelos tipos de vedação estudados, sendo verificado apenas efeito significativo da concentração de sacarose sobre essa variável (Figura 1b). O tipo de vedação dos frascos, além de interferir na passagem de luz para o interior dos frascos, altera a interceptação de luz pelos explantes, afetando, de acordo com SOUZA et al. (1999), sua capacidade de transpiração e, devido à retenção de água, a quantidade de massa fresca total produzida. A massa fresca das brotações foi influenciada unicamente pela concentração de sacarose no meio, exibindo resposta quadrática ao aumento da sacarose no meio de cultura (Figura 1d), e o máximo valor para essa variável foi obtido com $33,5 \mathrm{mg}$ $\mathrm{L}^{-1}$. A massa fresca e o comprimento das brotações apresentaram aumento proporcional até essa concentração de sacarose, em que o aumento de sacarose a partir desse limite contribui unicamente para o aumento do comprimento das brotações.

Em relação ao número de folhas formadas, houve interação entre os fatores concentração de sacarose e tipo de vedação dos frascos (Tabela 1). A vedação das tampas com algodão proporcionou o maior número de folhas formadas na ausência de sacarose no meio, enquanto que, nas maiores concentrações de sacarose, o melhor desempenho foi observado com a vedação com filme de PVC. O aumento da sacarose no meio de cultura não alterou o número de folhas formadas quando os frascos foram vedados com algodão (Figura 1c). Nos frascos vedados com filme de PVC, o número de folhas formadas aumentou linearmente com o aumento da sacarose no meio, indicando que pode ser obtido aumento do número de folhas formadas com a utilização de concentrações de sacarose superiores às concentrações utilizadas neste estudo. Para os frascos vedados com alumínio, o número de folhas formadas apresentou resposta quadrática frente às concentrações de sacarose, e a concentração mais eficiente foi de $22,8 \mathrm{mg} \mathrm{L}^{-1}$. Para a vedação dos frascos com alumínio, o uso de concentrações de acima de $30 \mathrm{~g} \mathrm{~L}^{-1}$ causou drástica redução do número de folhas formadas, assim como verificado por DAMIANI \& SCHUCH (2008) na multiplicação de mirtileiros (Vaccinium ashei) 'Delite'. A síntese de clorofila restringida pelo aumento da concentração de sacarose, associada ao aumento da concentração de etileno e à umidade no interior dos frascos e à diminuição da passagem de luz decorrente da vedação com papel alumínio, pode ter contribuído com a redução da atividade fotossintética, prejudicando a formação de novos tecidos foliares, assim como observado na formação de novos explantes.

De maneira geral, observou-se que a vedação dos frascos com algodão proporcionou maior número de folhas formadas na ausência de sacarose, não sendo observado efeito das concentrações de sacarose presentes no meio de cultura sobre o número de brotações e número de folhas formadas. O comprimento médio das brotações e a massa fresca total não diferiram entre os tipos de vedação empregados; porém, observou-se aumento dessas variáveis frente ao aumento da sacarose no meio de cultura. A vedação dos frascos com filme de PVC proporcionou o maior número de brotações e de folhas por explante quando utilizadas altas concentrações de sacarose.

\section{REFERÊNCIAS}

AFREEN, F. et al. Photoautotrophic culture of Coffea arabusta somatic embryos: photosynthetic ability and growth of different stage embryos. Annals of Botany, London, v.90, p.11-19, 2002 .

AHMAD, T. et al. Comparison of sucrose and sorbitol as main carbon energy sources in micropropagation of peach rootstock GF-677. Pakistan Journal of Botany, Karachi, v.39, n.4, p.1269-1275, 2007.

DAMIANI, C.R.; SCHUCH, M.W. Enraizamento in vitro de mirtilo em condições fotoautotróficas. Ciência Rural, Santa Maria, v.39, n.4, p.1012-1017, 2009. Disponível em: <http:/ / w w w. s c i e 1 o.b r/s c i e 1 o.ph p ? p i d = S 0103 84782009000400009\&script $=$ sci_arttext $>$. Acesso em: 15 jan. 2010. doi: $10.1590 / \mathrm{S} 0103-84 \overline{7} 82009005000031$.

DAMIANI, C.R.; SCHUCH, M.W. Multiplicação fotoautotrófica de mirtilo através do uso de luz natural. Revista Brasileira de Fruticultura, Jaboticabal, v.30, n.2, p.482487, 2008. Disponível em: <http://www.scielo.br/ scielo.php? script=sci arttext\&pid=S $0100-$ $29452008000200037 \& \operatorname{lng}=$ en $\&$ nrm $=$ iso\&tlng $=$ pt $>$. Acesso em: 15 jan. 2010 . doi: 10.1590/S0100-29452008000200037.

ERIG, A.C.; SCHUCH, M.W. Micropropagação fotoautotrófica e uso da luz natural. Ciência Rural, Santa Maria, v.35, n.4, p.961-965, 2005. Disponível em: $<\mathrm{http} / /$ www.scielo.br/scielo.php?pid=S0103$84782005000400039 \&$ script $=$ sci_arttext $>$. Acesso em: 15 jan. 2010. doi: $10.1590 / \mathrm{S} 0103-84782005000400039$. 
KOZAI, T; KUBOTA, C. Developing a photoautotrophic micropropagation system for woody plants. Journal of Plant Research, Tokyo, v.114, p.525-537, 2001.

KOZAY, T.; NGUYEN, Q.T. Photoautotrophic micropropagation of woody and tropical plants. In: JAIN, S.M.; ISHII, K. Micropropagation of woody trees and fruits. Dordrecht: Kluwer Academic, 2003. p.757-781.

LEBLAY, C. et al. Adventitious shoot regeneration from in vitro leaves of several pear cultivars (Pyrus communis L.) Plant Cell, Tissue and Organ Culture, Hague, v.25, p.99105, 1991.
QUOIRIN, M.; LEPOIVRE, P. Etude de milieux adaptes aux cultures in vitro de Prunus. Acta Horticulturae, Amsterdan, v.78, p.437-442, 1977.

RODRIGUES, M.M. et al. Propagação vegetativa in vitro e análise estrutural de macieira. Pesquisa Agropecuária Brasileira, Brasília, v.41, n.1, p.171-173, 2006. Disponível em: <http:// www.scielo.br/scielo.php?script $=$ sci_arttext\&pid $=\mathrm{S} 0100$ $204 X 2006000100024 \& \operatorname{lng}=\mathrm{en} \& \mathrm{nrm}=\mathrm{iso} \& \mathrm{t} \operatorname{lng}=\mathrm{pt}>$. Acesso em: 12 jan. 2010. doi: 10.1590/S0100-204X2006000100024.

SOUZA, C.M. De et al. Influência dos fatores físicos na regeneração de brotos em repolho. Ciência e Agrotecnologia, Lavras, v.23, n.4, p.830-835, 1999. 